\title{
Identification of a resistance gene Rpi-dlc1 to Phytophthora infestans in European accessions of Solanum dulcamara
}

\author{
Tomasz Michal Golas • Anne Sikkema • Jack Gros • Richard M. C. Feron • \\ Ronald G. van den Berg • Gerard M. van der Weerden · Celestina Mariani • \\ J. J. H. M. Allefs
}

Received: 16 April 2009/ Accepted: 22 October 2009/Published online: 20 November 2009

(C) The Author(s) 2009. This article is published with open access at Springerlink.com

\begin{abstract}
Initial screening of 14 Solanum dulcamara accessions enabled the identification of individuals resistant and susceptible to Phytophthora infestans. Crosses between contrasting genotypes resulted in three $\mathrm{F}_{2}-\mathrm{BC}_{1}$ populations segregating for resistance to late blight in a laboratory assay and under field conditions. Genetic profiling of one of these populations using 128 AFLP primers generated three markers linked to the resistant phenotype. Blast analysis of the sequenced markers resulted in a plausible gene position on the distal end of the long arm of chromosome 9 that could be confirmed by CAPS markers. Thus, we describe a first resistant gene, named Rpi-dlcl, from S. dulcamara, a Solanum species native to Europe. In
\end{abstract}

Communicated by G. Bryan.

T. M. Golas $(\bowtie) \cdot$ R. M. C. Feron

Plant Cell Biology Group, Radboud University,

Nijmegen, The Netherlands

e-mail: T.golas@science.ru.nl

T. M. Golas · R. M. C. Feron - C. Mariani Institute for Water and Wetlands Research,

Department of Experimental Botany,

Radboud University Nijmegen, Heyendaalseweg 135,

6525 AJ Nijmegen, The Netherlands

R. G. van den Berg

Biosystematics Group, Wageningen University,

Gen. Foulkesweg 37, 6703 BL

Wageningen, The Netherlands

G. M. van der Weerden

Institute of Water and Wetlands Research,

Botanical and Experimental Garden,

Radboud University, Toernooiveld 11,

6525 ED Nijmegen, The Netherlands addition, one population was tested for broadness of resistance responses using a set of seven additional $P$. infestans isolates, varying in virulence. This indicated the possible presence of additional Rpi genes.

\section{Introduction}

Of all the diseases, late blight caused by Phytophthora infestans (Mont.) de Bary poses the biggest threat to cultivated potato worldwide. Today, commercial potato crops are mainly protected by frequent application of fungicides (Fry 2007). However, the costs for fungicides and their application are considerable and their negative impact on the environment is now recognized (Haverkort et al. 2008).

Present Address:

R. M. C. Feron

Keygene N.V., Agro Business Park 90,

6708 PW Wageningen, The Netherlands

A. Sikkema · J. Gros · J. J. H. M. Allefs

Agrico Research, B.V. Burchtweg 17,

8314 PP Bant, The Netherlands

T. M. Golas - R. G. van den Berg - G. M. van der Weerden ·

C. Mariani - J. J. H. M. Allefs

Centre for BioSystems Genomics (CBSG),

P.O. Box 98, 6700 AB Wageningen, The Netherlands 
In many parts of the world outside Mexico, which is considered the center of the greatest genetic diversity of the pathogen, a strong increase in genetic variability has been observed, since the mid 1980s (Goodwin and Drenth 1997).

The apparent capacity of the pathogen to develop resistance to modern fungicides (Goodwin et al. 1996; Grünwald et al. 2001) necessitates constant vigilance by farmers. Therefore, breeders have been extremely interested in creating resistant cultivars from the beginning of the twentieth century onwards. The first breeding activities mainly focused on dominant resistance genes, as the complete resistance they conferred was easy to follow and promised a fast and effective way to protect crops against late blight. Single dominant resistance genes were initially identified in the Mexican species Solanum demissum and rather easily crossed into cultivated potato. By the 1970s, 11 such genes had been introgressed (Gebhardt and Valkonen 2001). However, their durability proved to be a problem, because virulent races of the pathogen appeared quickly, in a few cropping seasons, after market introduction (Wastie 1991) or even earlier, during the breeding process (Muller 1951). Nevertheless, by the mid-twentieth century, late blight was kept at a tolerable level, mainly by agricultural practices including moderately resistant cultivars (Fry and Goodwin 1997).

In the last two decades, progress in molecular biology allowed insight into the chromosomal positions of most of the genes introduced from $S$. demissum into $S$. tuberosum (Leonards-Schippers et al. 1992; Li et al. 1998; Huang et al. 2004, 2005; El-Kharbotly et al. 1994, 1996; Bradshaw et al. 2006) and two genes have now been cloned and characterized: $R I$ and $R 3 a$ (Ballvora et al. 2002; Huang et al. 2005).

Currently, apart from $S$. demissum, other wild American species of the genus Solanum are considered as possible sources of resistance, but introgression of these genes into cultivars often requires interspecific bridge crosses. In the Mexican species, $S$. bulbocastanum three genes were identified; the allelic $R B$ (Helgeson et al. 1998; Naess et al. 2000; Song et al. 2003) and Rpi-blbl (Van der Vossen et al. 2003) on chromosome 8, Rpi-blb2 on chromosome 6 (Van der Vossen et al. 2005) and Rpi-blb3 on chromosome 4 (Park et al. 2005). In the wild species $S$. pinnatisectum, a dominant gene Rpil was mapped by Kuhl et al. (2001) to chromosome 7. On chromosome 9, genes from S. mochiquense named Rpi-mcql, S. phureja named Rpi-phul and S. venturii named: Rpi-vnt1.1, Rpi-vnt1.2 and Rpi-vnt1.3, were identified (Smilde et al. 2005; Sliwka et al. 2006; Foster et al. 2009; Pel et al. 2009). Two S. berthaultii genes Rpi-berl and Rpiber2 were mapped on chromosome 10 (Park et al. 2009); also, $S$. microdontum, $S$. paucissectum and $S$. stoloniferum are considered as resistance sources (Sandbrink et al. 2000; Villamon et al. 2005; Tan et al. 2008; Wang et al. 2008). All of these species are tuber-bearing Solanum species of section Petota. Up til now, only one resistant gene has been described in the non-tuber bearing representatives of the genus Solanum: the South American species $S$. caripense carries a major R-gene that has been mapped on chromosome 9 (Trognitz and Trognitz 2004; Nakitandwe et al. 2007).

In Europe, in contrast to the new world, only few native solanaceous species are present. Among them are $S$. nigrum, an annual hexaploid weed, and the perennial diploid S. dulcamara, also known as bittersweet or climbing nightshade. Bittersweet is an easy to recognize, out-crossing species with a low level of genetic variation that occupies a range of habitats (Golas et al. 2009, submitted). In the Netherlands, it can often be found in the vicinity of commercial potato fields. S. dulcamara has been known for a long time as a host for $P$. infestans under natural conditions (de Bary 1876), but it hardly suffers from late blight attacks, even under conditions highly favorable for disease outbreaks that cause severe crop losses of organically produced potatoes (Golas et al. 2009, in preparation).

The goal of this study was to unravel the genetic factors that cause the observed high level of resistance of $S$. $d u l$ camara against $P$. infestans present in individuals from natural populations. The screening of diploid S. dulcamara accessions usually revealed a strong resistance, but occasionally susceptibility. The availability of both resistant and susceptible variants made it possible to start a genetic study on the nature of resistance to late blight in this European species. This paper describes the identification, field assessment, and mapping of a first resistance gene named Rpi-dlcl, in three accessions of $S$. dulcamara.

\section{Materials and methods}

\section{Plant material}

Fourteen S. dulcamara accessions (Table 1), each represented by five individuals, were obtained from the collection of the Botanical and Experimental Garden of Radboud University Nijmegen (The Netherlands). Accessions, together with developed segregating mapping populations were cultivated at the Botanical and Experimental Garden, Nijmegen, The Netherlands. Passport data concerning the accessions used can be found at http://www-athos.bgard. science.ru.nl. Seeds were sprayed with GA3 (Duchefa, Haarlem, The Netherlands) and germinated at $30^{\circ} \mathrm{C}$ on moist soil. After 2 weeks, seedlings were transplanted to $1 \mathrm{~L}$ pots filled with a standard soil mixture (Lentse Potgrond no. 4). Plants were grown in the glasshouse under long day conditions (16 h day/8 h night) with supplementary light of high pressure sodium lamps (SON-T 600W) and were regularly fertilized with $2 \mathrm{~g} / \mathrm{L}$ of Kristallon 
Table 1 Accessions of $S$. dulcamara used to screen the level of resistance under field conditions and in detached leaf assays in summer 2004

\begin{tabular}{llll}
\hline Accession code & Country of origin & \multicolumn{2}{l}{ Resistance screening } \\
\cline { 3 - 4 } & & $\mathrm{R}$ & $\mathrm{S}$ \\
\hline 85003 & Germany & 4 & 1 \\
88034 & Austria & 5 & 0 \\
88057 & France & 5 & 0 \\
91008 & Switzerland & 5 & 0 \\
91046 & Italy & 5 & 0 \\
91081 & France & 4 & 1 \\
92023 & Belgium & 5 & 0 \\
92109 & France & 5 & 0 \\
92195 & Poland & 5 & 0 \\
93233 & The Netherlands & 5 & 0 \\
94001 & Great Britain & 3 & 2 \\
A4081 & Unknown & 5 & 0 \\
A4088 & Unknown & 5 & 0 \\
A4148 & Poland & 5 & 0 \\
\hline
\end{tabular}

The first column is an abbreviated accession code. The second column indicates the country of origin of the accession. The third column indicates the number of resistant/susceptible individuals within each accession under laboratory and field conditions

Blauw (Yara Benelux B.V. Vlaardingen). During winter, plants were kept in a cold glasshouse.

\section{Crosses}

All crosses that led to $\mathrm{F}_{1}$ and $\mathrm{F}_{2}-\mathrm{BC}_{1}$ populations and the increased population 05-346 were performed under greenhouse conditions in the winter of 2004, the summer of 2005 and the summer of 2006. Just before opening, flowers were emasculated and hand pollinated the next day. In all cases, the susceptible parent was used as a pollen donor. After 6 weeks of pollination, seeds were extracted from mature berries and stored in paper bags at $4^{\circ} \mathrm{C}$.

In the present study, three crosses were used to investigate the Rpi-dlcl resistance gene. Cross 05-188: [(92023$\left.\left.4_{\mathrm{Rp}} \times 94001-2_{\mathrm{Sp}}\right) \times 94001-2_{\mathrm{Sp}}\right]$ was constructed using a resistant parent, identified within the 92023-4 (Rp) accession collected in Belgium at Bel Herbeumont, and a susceptible parent 94001-2 (Sp), collected in Great Britain at St. Aldhelm's Head. To obtain population 05-203: [(88057$\left.\left.2_{\mathrm{Rp}} \times 91081-4_{\mathrm{Sp}}\right) \times 94001-5_{\mathrm{Sp}}\right]$ a resistant parent $88057-2$ (Rp) collected at Duinkerken (France) was first crossed with a susceptible plant 91081-4 (Sp) collected in France at Fort-Mahon-Plage and than with another susceptible parent 94001-5 (Sp), collected in Great Britain at St. Aldhelm's Head. Cross 05-346: [(A4148-3 $\mathrm{Rp}_{\mathrm{R}} \times$ 94001-2 $\left.\mathrm{Sp}\right) \times$ 94001$2_{\mathrm{Sp}}$ ] contains a Polish resistant genotype of unknown collection place A4148-3 (Rp), crossed twice with the susceptible parent 94001-2 (Sp).

\section{Phytophthora infestans isolates}

Phytophthora infestans isolates: 90128, Ipo82001 collected in The Netherlands and Belgium, respectively (provided by V. Vleeshouwers Wageningen University, The Netherlands) and isolate Ipo655 collected in The Netherlands (Table 2) were used in detached leaf assays (DLAs). For characterization of the broadness of the resistance spectrum, an additional set of seven isolates was kindly provided by F. Govers (Wageningen University, The Netherlands) (Table 2). The virulence of each isolate was determined by performing DLAs with the $S$. demissum differentials set R1-R11 obtained from Wageningen University (Flier et al. 2003).

\section{Resistance screening}

For the initial field trial, $S$. dulcamara plants approximately 8 weeks old: (5 plants per accession) were vegetatively propagated in April 2004. Cuttings with one node bud were obtained, placed in moist soil and covered with plastic foil to increase the humidity for a period of 4 days. A minimum of three rooted cuttings was obtained per plant and potted in the second half of May 2004. On 22 June 2004, three plant plots were planted on an experimental field near Marknesse (The Netherlands), as a part of much larger trial, where potato breeding material was tested for late blight resistance. On 28 July, spray inoculation was carried out with a suspension of $P$. infestans [complex A2 isolate Ipo82001, race 1, 2, 3, 4, 5, 6, 7, 10 and 11 (Flier et al. 2003)]. Subsequently, segregating populations and individuals of an extended population coded 05-346 were screened under field conditions in the years 2005-2008.

Table 2 Virulence spectrum of $P$. infestans isolates used in detached leaf assays and field experiments

\begin{tabular}{ll}
\hline Isolate & Virulence profile \\
\hline T30-4 & 0 \\
88133 & 0 \\
MP806 & $1,3,4$ \\
MP722 & $1,2,3,4$ \\
88069 & $1,2,3,4,6,7$ \\
US618 & $1,2,3,4,6,10$ \\
90128 & $1,2,3,4,6,7,10,11$ \\
89148.09 & $1,2,3,4,6,7,10,11$ \\
Ipo82001 & $1,2,3,4,6,7,10,11$ \\
Ipo655 & $1,2,3,4,5,6,7,10,11$ \\
\hline
\end{tabular}

The virulences of the isolates used were determined using the $S$. demissum derived set of differentials R1-R11 
Plants were propagated and planted as described above, but nine rooted cuttings were produced per individual, instead of three (plots were planted in 3 randomized blocks with each plot containing 3 plants). Planting, inoculation and resistance assessment were done essentially as in the previous year. Observations of disease development were carried out from mid of August till end of September, as in 2004. Four types of observations were made: the estimated amount of green and healthy tissue present on the plants, the estimated severity of yellowed and dropped leaves, the sporulation intensity and the total impression of plant fitness. Each of these parameters was given a score on a scale from 3 to 8 , where 3 indicates the most susceptible/ unhealthy plant and 8 the most resistant/healthy plant. A value for a field resistance of a given individual was calculated as the average score for all observations made during a testing season. The score of 3 was the lowest score measured for a susceptible phenotype, and a score of 8 indicated immunity to late blight.

Detached leaf assays were performed as described by Vleeshouwers et al. (1999). Fresh sporangia were produced in a weekly cycle on detached leaves of the susceptible potato cultivar Bintje. Trays with leaves put into water soaked florist foam were kept in closed plastic boxes for a period of 1 week in a climate chamber set at $18^{\circ} \mathrm{C}(16 \mathrm{~h}$ day/ 8 h night). A fresh suspension of zoospores was produced by rinsing around five infected leaflets in approximately 200$\mathrm{ml}$ tap water with a few drops of raw potato tuber sap added to it. Following the incubation of the sporangial suspension at $4^{\circ} \mathrm{C}$ to induce zoospore release, inoculation was carried out by applying two $10 \mathrm{ml}$ drops of suspension on the abaxial side of the leaves. Infection severity was evaluated 7 days after the inoculation. Leaves showing clear sporulation were classified as susceptible, whereas leaves showing a necrotic response at the site of the inoculation or a lesion without sporulation were classified as resistant.

DNA isolation and genetic analysis

Total genomic DNA was isolated from young leaves using the Wizard genomic DNA purification kit (Promega), according to the protocol supplied by the manufacturer. A pestle was used to grind approximately $40 \mathrm{mg}$ of fresh plant material in liquid nitrogen to a fine powder. Following the extraction, the concentration of DNA was measured using a spectrophotometer (Pharmacia Biotech: GeneQuant II) and the quality of the DNA was checked by electrophoresis in a $1 \%$ agarose gel (Eurogentec, Belgium) stained with EtBr.

Amplified fragment length polymorphism (AFLP $\left.{ }^{\circledR}\right)$ analysis was performed according to Vos et al. (1995). The initial digestion of total genomic DNA was done using EcoRI and MseI restriction enzymes (Fermentas,
Germany). Pre-amplification and selective PCR were performed using thermocycler GeneAmp9600 (Perkin Elmer, USA). Visualization of selective PCR products was done by labeling EcoRI primers with radioactive gamma- ${ }^{33} \mathrm{p}$ (MP Biomedicals, USA). Labeled selective PCR products were separated on a $5 \%$ polyacrylamide gel (Duchefa, The Netherlands), dried on paper and visualized by exposure to X-ray film (Kodak BIOMAX MR) for $48 \mathrm{~h}$. Gels were scored manually.

The bulk segregant analyses (BSA) approach was used (Michelmore et al. 1991) to obtain AFLP fragments cosegregating with resistance in mapping populations. Two bulks were constructed by combining DNA of five, either resistant or susceptible individuals. DNA samples in each bulk were mixed after the pre-amplification step in equal concentrations. Bulks and parental DNA samples were analyzed using $128 \mathrm{MseI} / E c o$ RI AFLP primer combinations. Primer combinations that yielded an AFLP product only in the resistant parent and in the resistant bulk, but not in the susceptible parent and in the susceptible bulk were identified and applied to all the individuals of a segregating population. AFLP fragments linked to the resistant phenotype were excised from the gel and subsequently, DNA was eluted and re-amplified under the same conditions as for the pre-amplification. PCR products were cloned into pGEM-T Easy (Promega, USA) and sequenced using the $\mathrm{CEQ}^{\mathrm{TM}}$ DTCS Quick Start Kit (Beckman Coulter $8000^{\mathrm{TM}}$ ).

To develop markers in the region of Rpi-dlcl sequence information from GABI (http://www.gabipd.org/database/ maps.shtml) and SGN (http://sgn.cornell.edu/cview/map.pl? map_id=9\&show_offsets=1\&show_ruler=1) databases were used for primer design. Markers used for mapping the Rpidlcl gene were also applied to the diploid potato mapping population "SH $\times$ RH" (van Os et al. 2006; provided by $\mathrm{H}$. van Eck Wageningen University, The Netherlands) containing 101 offspring. Polymorphic markers were searched by digestion of PCR generated fragments using 12 tetracutter restriction enzymes (AluI, HpaII, RsaI, DpnII, MseI, BsuRI, HhaI, NlaIII, DdeI, HinfI, HpyCH4IV and TaqI). Genetic distances in cM were calculated based on the number of recombinants. Publicly available potato and tomato genetic maps from the GABI and SGN were included for comparison of marker positions and synteny.

\section{Results}

Populations segregating for the resistance

An initial screening of the $14 \mathrm{~S}$. dulcamara accessions, challenged under field conditions in the year 2004 with Ipo82001 and in DLA with isolates Ipo82001 and 90128 revealed a considerable level of variation in the response to 
$P$. infestans. Within the tested set of accessions, both resistance and susceptibility to late blight among individuals was identified (Table 1). Under field conditions, the most resistant individuals remained free of symptoms. On less resistant accessions, infections appeared on young stems and mature leaves that later dropped off. On two highly susceptible genotypes from accession 94001, intensive sporulation was observed and those plants were killed. In DLA, localized necrosis at the site of inoculation and lesions without noticeable sporulation were observed on resistant genotypes. On moderately resistant and susceptible individuals, a clear sporulation 7 days after inoculation was observed. To develop segregating populations, 39 crosses were made between resistant and susceptible genotypes of $S$. dulcamara. $\mathrm{F}_{1}$ populations were tested in DLA and one population, 05-40 $\left(92023-4_{R p} \times 94001-2_{S p}\right)$ containing 49 offspring clones was tested in the field in 2005. In DLA, $F_{1}$ populations generally did not segregate in a reproducible manner and no clear segregation was observed for population 05-40 (data not shown). Also, the field test conducted in 2005 gave no clear segregation in population $05-40$, but rather a broad phenotypic range that was skewed towards susceptibility (Fig. 1). Further, the susceptible parent had a low score of 3 and the resistant parent the highest score of 8 . Offspring plants showed phenotypes that were all intermediate in comparison to the parents.

From each $F_{1}$ population, the resistant individual(s) based either on DLA or field data were selected and crossed again to one of the available susceptible parents. Forty-four $\mathrm{BC}_{1}$ populations obtained in this way were tested in DLA. Population 05-188, was obtained after backcrossing the resistant individual no. 48 from population 05-40 to the susceptible parent 94001-2. This population, containing 40 individuals, was selected for a field test carried out in the growing season 2006, to track the changes in response to the late blight between the $\mathrm{F}_{1}$ and $\mathrm{BC}_{1}$ generation. In general, the resistance level of the 05188 offspring plants was scored significantly higher than that of population $05-40$. In the previous season, population 05-40 showed a weak binominal distribution for field resistance, whereas population 05-188 displayed rather clear segregation, close to a $1: 1\left(\chi^{2}=3 ; P=0.083\right)$ of susceptible individuals having the resistance score of 5.5 or lower and resistant individuals scoring 5.5 or higher (Fig. 1).

In another pair of $\mathrm{BC}_{1}$ populations, coded 05-203 and 05-346 containing 45 and 52 individuals, respectively, clear and reproducible segregation in DLA was observed (population 05-203: $\chi^{2}=0.35 ; P=0.55$; population 05346: $\chi^{2}=1.92 ; P=0.16$; DLA data not shown). Both populations were segregating roughly according to a $1: 1$ ratio after inoculation with isolates 90128 or Ipo82001 in replicated DLAs.

Molecular analysis of segregating populations

Amplified fragment length polymorphism analyses were conducted on population 05-203 and this ultimately yielded three co-segregating fragments: two at $5 \mathrm{cM}$, and one fragment at $2 \mathrm{cM}$ distance from a gene that putatively was designated Rpi-dlcl. Primers were designed based on the sequence of these AFLP markers and tested on a preamplification mix to confirm whether the proper fragments were isolated. Two out of three primers pairs reproduced the original segregation pattern of the AFLP markers, thereby confirming correct cloning. These two confirmed markers (eACTmCAC with primer pair 5'-3'-catggct tcccgtactgaat and $5^{\prime}-3^{\prime}$-tcacctttccaggcaaaac and eACT mCGC 5'-3'-cgcacaatttgtgcatcgcg and 5'-3'-cactgtagtagc atatttgg) were tested on genomic DNA of population 05203 and both amplified a product of the expected size in all individuals, but the amount of PCR product was considerably lower in the susceptible parent, susceptible offspring and recombinants. As a next step toward the mapping of Rpi-dlcl, the sequences of the markers eACTmCAC and eACTmCGC were blasted against plant genomic sequences available in public databases. The highest sequence

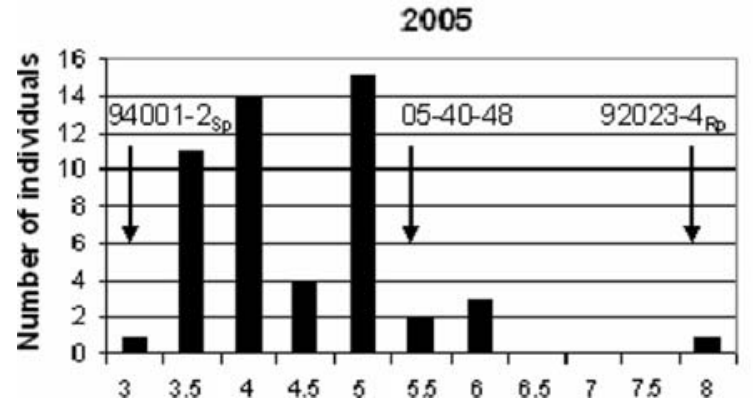

Fig. 1 Distributions of the resistant phenotypes in $F_{1}$ cross 05-40 containing 49 plants (left side) and in $\mathrm{BC}_{1}$ cross $05-188$ containing 40 plants (right side) under field conditions. On the $X$ axis is indicated

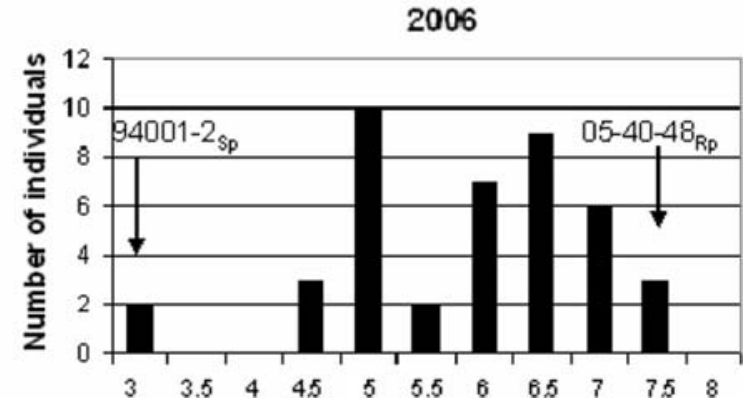

mean disease severity where 3 is most susceptible and 8 is most resistant. On the $Y$ axis, the number of individuals classified to each phenotypic group is given 
Table 3 Markers that were found to co-segregate with the Rpi-dlc1 gene on chromosome 9 in three independent segregating populations of $S$. dulcamara

\begin{tabular}{|c|c|c|c|c|c|c|c|}
\hline \multirow[t]{2}{*}{ Marker } & \multirow[t]{2}{*}{ Primer $\left(5^{\prime}-3^{\prime}\right)$} & \multirow[t]{2}{*}{$T_{\mathrm{m}}\left({ }^{\circ} \mathrm{C}\right)$} & \multirow[t]{2}{*}{ Fragment size (bp) } & \multicolumn{3}{|c|}{ Population/rest. enzyme } & \multirow[t]{2}{*}{ Source } \\
\hline & & & & $05-188$ & $05-203$ & $05-346$ & \\
\hline $\mathrm{S} 2 \mathrm{~g} 3$ & $\begin{array}{l}\text { GGGTGTGAATACTTTTACTC } \\
\text { CAATGTAAAAACTCAAGCCC }\end{array}$ & 48 & 800 & AluI & AluI & n.p. & GABI \\
\hline TG591A-L & $\begin{array}{l}\text { ACAATCGCTAGCGGTATACC } \\
\text { GAAACTTTATAGGCACGTCC }\end{array}$ & 54 & 500 & BsuRI & BsuRI & n.p. & SGN \\
\hline GP101 & $\begin{array}{l}\text { GGCATTTCTATGGTATCAGAG } \\
\text { GCTTAACATGCAAAGGTTAAA }\end{array}$ & 52 & 750 & n.d. & n.p. & AluI & GABI \\
\hline GP41 & $\begin{array}{l}\text { CAGGAGATCCATCTCTCAAG } \\
\text { CTGCAGTAAAGTGCATTCGG }\end{array}$ & 51 & 1,200 & n.d. & RsaI & AluI & GABI \\
\hline CT220est & $\begin{array}{l}\text { AGAGTAGTGTGATTGAGACG } \\
\text { GATGATCATCGCAGTAGAGG }\end{array}$ & 48 & 900 & n.d. & NlaIII & n.p. & SGN \\
\hline T0521 & $\begin{array}{l}\text { CAGTCGGCGCAGTTTCAAAA } \\
\text { GCATTACCTAGATCAATGCC }\end{array}$ & 59 & 1,300 & n.d. & n.p. & DdeI & SGN \\
\hline S1d11 & $\begin{array}{l}\text { GTAACTCTTCCTATTGTACTC } \\
\text { CCAATAGTCATTGTAAGGCGC }\end{array}$ & 58 & 300 & n.d. & a.s. & a.s. & GABI \\
\hline S1d5-a & $\begin{array}{l}\text { CGCCTCTTTCTCTGAATTTC } \\
\text { GATCTGGGATGGTCCATTC }\end{array}$ & 57 & 550 & n.d. & n.p. & a.s. & GABI \\
\hline
\end{tabular}

N.p. no polymorphism, n.d. not determined, a.s. allele specific

homology of the AFLP fragment amplified by eACTmCAC (accession number: FJ769334) was with the S-adenosyl-L-homocysteine hydrolase gene from S. tuberosum, found in the GABI database, indicating two possible positions for Rpi-dlcl: one on potato chromosome 9 between markers GP41 and CT220 and the other on chromosome 12 between markers GP122 and GP264. To verify both putative genomic positions of Rpi-dlcl, four primer pairs were developed based on the available sequences of these markers. Pairs yielding clear PCR products were used to search for polymorphisms between the parental genotypes of population 05-203. Therefore, PCR products were digested with a set of 12 restriction enzymes. As a first result, marker GP41, after digestion with $R s a \mathrm{I}$, revealed a polymorphism between the parents of population 05-203. Subsequently, GP41/RsaI was tested on the entire population 05-203 and was indeed found to co-segregate with the phenotypic scores. Positions on chromosome 12 did not yield a polymorphic band. Subsequently from available databases, a set of 28 markers, previously mapped in the region of GP41 in potato or tomato, were selected and primers were developed on the basis of their available sequences. In total, 16 primer pairs yielded amplification products in S. dulcamara and 4 of them (S2g3/AluI; TG591A-L/BsuRI; CT220est/NlaIII; S1d11/allele specific) were polymorphic and co-segregated with resistance in population 05-203 (Table 3). The other two segregating populations, $05-188$ and $05-346$, were also tested for co-segregation at the Rpi-dlcl locus with the set of markers used in population 05-203 (Table 3). In both populations, segregation of the identified polymorphisms was consistent with phenotypic data. In population 05-346, originally consisting of 52 offspring clones, recombinants were identified between Rpi-dlcl and a set of five available polymorphic markers. This population was subsequently enlarged to 302 individuals to generate a more detailed map of the Rpi-dlcl locus. In total, 23 crossing-over events were identified between markers GP101 and the T0521 marker $(7.6 \mathrm{cM})$. T0521 is positioned more distal to the centromere than marker GP101. However, due to the loss of 7 of these recombinant genotypes, only 16 could eventually be phenotyped in the field and tested with the available remaining three polymorphic markers. To be able to compare the genetic distances obtained for GP101 and T0521, genetic distances between S1d5-a, GP41 and S1d11 were calculated for 210 individuals/16 recombinants (Fig. 2b). In the enlarged population 05-346 each marker appeared to be separated by at least one crossing over. This allowed narrowing down the genetic region containing Rpi-dlcl by comparing the presence/absence of a marker with resistance/susceptibility of the recombinant. Between markers S1d11 and T0521, one resistant recombinant was identified containing all markers except T0521, excluding the possible presence of Rpi-dlcl near T0521. Recombinant containing T0521 and S1d11 could not be used due to the 


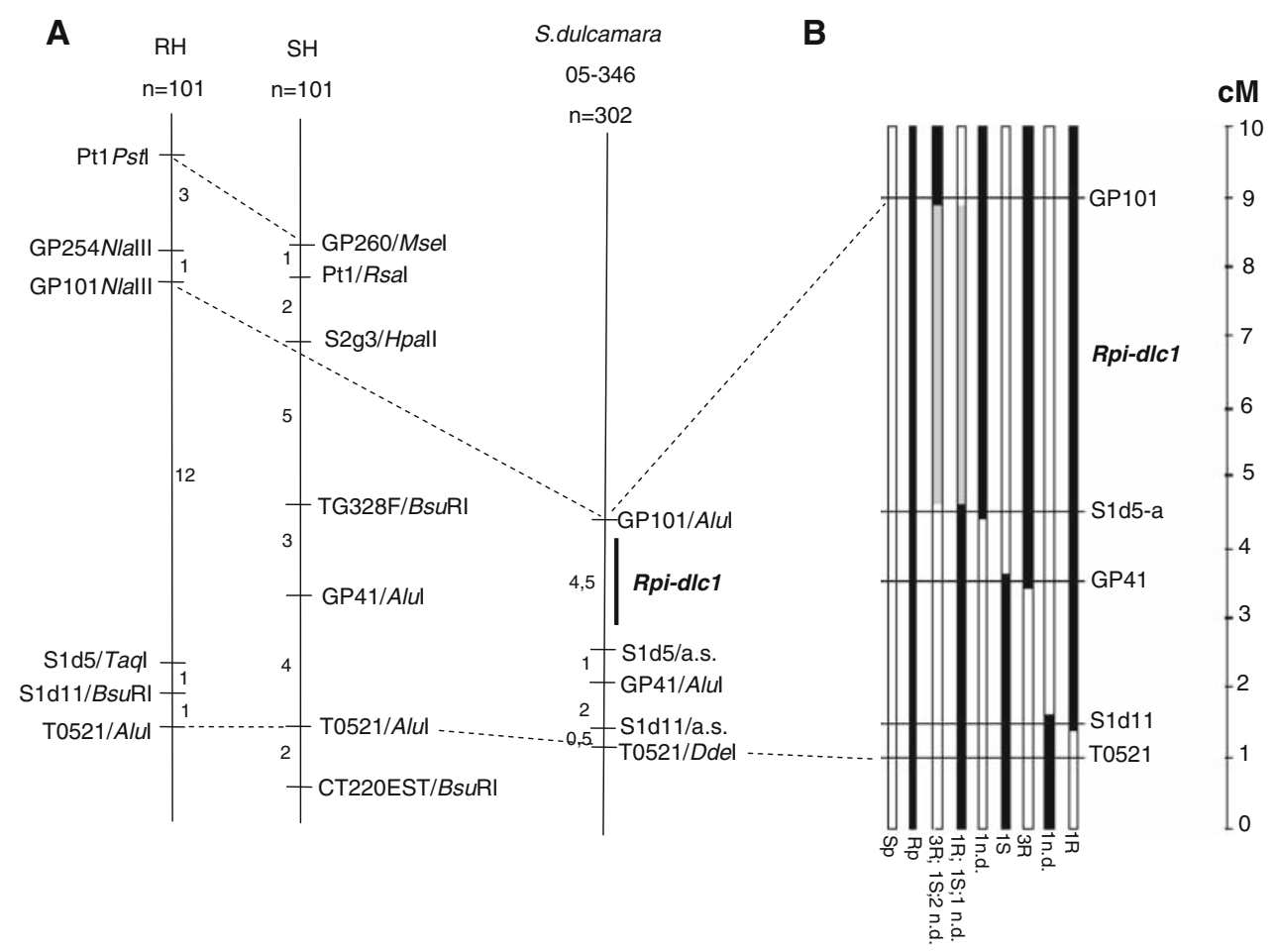

Fig. 2 a Maps of chromosome 9 of potato $(\mathrm{RH} \times \mathrm{SH})$ and $S$. dulcamara near the Rpi-dlc1 locus. Numbers indicate genetic distances in $\mathrm{cM}$ between markers. $\mathbf{b}$ Schematic representation of the genomic region in the population 05-346 containing Rpi-dlc1. Black bars represent resistant, white bars susceptible marker profiles and gray bars indicate the genomic region where Rpi-dlcl was mapped. At the bottom end of the bars results from the field experiment are presented. Numbers indicate number of offspring with clear

lack of reliable phenotypic results. Subsequently, three resistant recombinants were identified that contained GP101, S1d5-a and GP41 markers, but not S1d11. In addition, a susceptible recombinant was identified that contained GP41, S1d11 and T0521, but not GP101 and S1d5-a, thus excluding the GP41 region. Finally two sets of recombinants; one containing only GP101 and second containing all other markers except GP101 were found to contain both resistant and susceptible genotypes, indicating that the Rpi-dlcl locus is localized somewhere between the GP101 and S1d5-1 markers (Fig. 2b).

Population 05-346 was also used to compare the genomic region of the Rpi-dlcl locus of S. dulcamara to a corresponding region in the potato $\mathrm{SH} \times \mathrm{RH}$ mapping population The five markers used to map the Rpi-dlcl locus in population 05-346 were successfully mapped on the genetic map of potato $\mathrm{SH} \times \mathrm{RH}$ (Fig. 2a). All markers were mapped in the same order in $S$. dulcamara and $\mathrm{SH} \times \mathrm{RH}$ except S1d5-a, and GP41, where inversion between these markers was detected. Significant differences were also present in the calculated genetic distance between markers GP101 and S1d5-a (Fig. 2a). phenotype, $R$ is resistant, $S$ susceptible and n.d. not determined phenotype. $R p$ and $S p$ are the resistant and susceptible parents, respectively. Genetic distances between markers GP101 and T0521 were calculated for 302 individuals. Among these, 23 recombinants were found. Genetic distances for the remaining three polymorphic markers S1d5-a, GP41 and S1d11 were calculated using 210 individuals and 16 recombinants that were tested in the field. On the right a $\mathrm{cM}$ scale

Broadness of resistance

To test the spectrum of resistance governed by Rpi-dlcl, 20 resistant and 20 susceptible genotypes from population 05 346 were tested in DLAs with a set of eight $P$. infestans isolates varying in virulence profile (Table 2). Isolates 90128 and Ipo82001 were used for reference. The resistant parent $142-12_{\mathrm{Rp}}$ of $05-346$ was found to be resistant to all isolates, whereas the susceptible parent $94001-2_{\mathrm{Sp}}$ appeared to be susceptible to all isolates. The Rpi-dlcl gene in resistant individuals of population 05-346 was found functional to isolates 90128, Ipo82001 and additionally to T30-4. Phenotypes scored upon infection with 88069,88133 and 89148.09 were skewed towards susceptibility (resistance/susceptibility 9/31; 4/36; 8/32, respectively). More resistant individuals were found when isolates MP722 and Ipo655 were used (13/27 and 16/26 resistant/susceptible, respectively). A 1:1 segregation was detected with isolates US618 (19/21) and MP806 (21:19), although segregation in resistant and susceptible individuals was not according to the assumed presence or absence of Rpi-dlc1. Individual 346-41 from this population was 
resistant to all tested isolates, and 346-57 was susceptible only to isolate US618 (Table 4).

\section{Discussion}

The goal of this study was to identify the genetic factors responsible for the elevated level of resistance as observed in S. dulcamara accessions against P. infestans (Golas et al. submitted). In this paper, we have described the identification, field assessment, and mapping of a first resistant gene of $S$. dulcamara against late blight that is designated Rpi-dlcl. Here, we follow the system of Van der Vossen et al. (2003) for naming newly identified resistance genes against late blight. This system suits for easy connection of the resistance gene with the species in which it was originally identified.

Renewed interest in R-gene-based resistance against late blight resulted in the identification of numerous wild Solanum species as valuable sources of resistance, other than the previously exploited $S$. demissum. However, for some Solanum species, high levels of resistance or nonhost resistance create a difficulty in the sense that susceptible genotypes suitable for genetic studies are not available. Problems of that nature also apply to the European species S. dulcamara and S. nigrum (Cooke et al. 2002; Flier et al. 2003; Lebecka 2008). In the case of bittersweet, susceptibility to late blight was reported earlier, but it is relatively rare, and often a susceptible reaction in the DLA experiments does not necessarily indicate full susceptibility under field conditions. In our initial experiments, we used isolates of $P$. infestans that had a rather broad spectrum of virulence and were considered as aggressive (Flier et al. 2003). The resistance assays on various accessions of $S$. dulcamara were done both in the field and under laboratory conditions and resulted in the identification of susceptible $S$. dulcamara genotypes having a stable, reproducible, highly susceptible phenotype. We used a similar approach in parallel to identify susceptible individuals in accessions of Solanum species of section Solanum (S. nigrum, S. sarrachoides, S. scabrum and S. villosum), but were unable to identify reliable susceptible plants (Golas et al. 2009, unpublished results) and we failed to setup populations in these species that segregated for resistance to late blight.

Currently, there is limited overall knowledge about $S$. dulcamara, and this species was never considered as a possible source of resistance against late blight. Also, to our knowledge, the genetic basis of resistance to $P$. infestans in S. dulcamara was not known. In several solanaceous crop plants, especially potato and tomato, resistance genes to different pathogens have been identified and placed on the genetic maps. The majority of them group together in clusters of genes called "resistance hot spots"
(Gebhardt and Valkonen 2001). Rpi-dlcl was found to map within such a cluster on the long arm of chromosome 9, where resistance genes to various pathogens have been mapped (Brommonschenkel and Tanksley 1997; Tommiska et al. 1998; Rouppe van der Voort et al. 2000; Chunwongse et al. 2002; Trognitz and Trognitz 2004; Smilde et al. 2005; Nakitandwe et al. 2007). Rpi-dlcl appeared to map in the proximity of another gene, Rpi-mcql from the tuber-bearing species S. mochiquense (Smilde et al. 2005). However, the RFLP marker TG328, found to be linked to Rpi-mcql did not amplify in any of $S$. dulcamara resistant parents used to develop the segregating populations. This indicates that the region of Rpi-mcql is not present in $S$. dulcamara and therefore might suggest that Rpi-mcql and Rpi-dlcl are different loci. However, their eventual relationship requires additional fine mapping. Comparison of the marker order in this region on $S$. dulcamara chromosome 9 with $S$. tuberosum showed that $S$. dulcamara shares a basic level of genetic synteny with these species. However, markers that were mapped on the genetic map did show some inversions in S. dulcamara. Moreover, most of the markers localized on the genetic map of potato did not differ significantly from the genetic distances observed in $S$. dulcamara using the same markers. However, only about half of the tested markers could be amplified in the $S$. dulcamara genome. This situation indicates that there is some divergence caused by lack of basic sequence similarity between potato, tomato and bittersweet in that region, which is logic in the light of the taxonomic position of $S$. dulcamara relative to $S$. tuberosum and S. lycopersicum (Weese and Bohs 2007).

Although the phenotypes of population 05-188 obtained from the field showed a binominal distribution, plants from the resistant group of the segregating population were not immune to late blight. Based on that, we concluded that this gene behaves as a QTL under field conditions and this gene has rather a slowing down effect on disease progress, than that it confers immunity. Possessing a QTL nature, Rpi-dlcl was difficult to track in DLA experiments, thus field data were necessary to obtain clear phenotypes. The tested broadness of resistance using one of the segregating population with additional isolates revealed the possibility of the presence of additional Rpi genes, different from Rpidlcl.

Rpi-dlcl or at least allelic versions of the gene were identified in three independent populations derived from parents originating from geographically different regions of Europe (France, Belgium and Poland). Experiments that have been carried out to study the genetic variation of European S. dulcamara revealed high-molecular similarity (above 90\%) between accessions, even among those geographically separated (Golas et al. 2009, submitted). Finding the same gene (or its allelic versions) present in 
Table 4 Results from the detached leaf assay of resistant parent (142-12Rp), susceptible parent (94001-2Sp) and 20 resistant and 20 susceptible individuals from population 05-346 inoculated with 10 P. infestans isolates

\begin{tabular}{|c|c|c|c|c|c|c|c|c|c|c|}
\hline \multirow[t]{2}{*}{ Genotype } & \multicolumn{10}{|c|}{ Phytophthora infestans } \\
\hline & 90128 & T30-4 & Ipo82001 & 88069 & MP722 & 88133 & 89148.09 & US618 & MP806 & Ipo655 \\
\hline $142-12 R p$ & $\mathrm{R}$ & $\mathrm{R}$ & $\mathrm{R}$ & $\mathrm{R}$ & $\mathrm{R}$ & $\mathrm{R}$ & $\mathrm{R}$ & $\mathrm{R}$ & $\mathrm{R}$ & $\mathrm{R}$ \\
\hline $94001-2 \mathrm{Sp}$ & $\mathrm{S}$ & $\mathrm{S}$ & $\mathrm{S}$ & $\mathrm{S}$ & $\mathrm{S}$ & $\mathrm{S}$ & $\mathrm{S}$ & $\mathrm{S}$ & $\mathrm{S}$ & $\mathrm{S}$ \\
\hline $346-1$ & $\mathrm{R}$ & $\mathrm{R}$ & $\mathrm{S}$ & $\mathrm{S}$ & $\mathrm{S}$ & $\mathrm{S}$ & $\mathrm{S}$ & $\mathrm{S}$ & $\mathrm{S}$ & $\mathrm{S}$ \\
\hline $346-2$ & $\mathrm{R}$ & $\mathrm{R}$ & $\mathrm{S}$ & S & $\mathrm{R}$ & $\mathrm{S}$ & S & $\mathrm{S}$ & $S$ & $\mathrm{~S}$ \\
\hline $346-3$ & $\mathrm{R}$ & $\mathrm{R}$ & $\mathrm{S}$ & $\mathrm{S}$ & $\mathrm{R}$ & $\mathrm{S}$ & $\mathrm{S}$ & $\mathrm{R}$ & $\mathrm{S}$ & $\mathrm{S}$ \\
\hline $346-4$ & $\mathrm{R}$ & $\mathrm{R}$ & $\mathrm{S}$ & $\mathrm{S}$ & $\mathrm{R}$ & $\mathrm{S}$ & $\mathrm{S}$ & $\mathrm{S}$ & $\mathrm{S}$ & $\mathrm{S}$ \\
\hline $346-5$ & $\mathrm{~S}$ & $\mathrm{~S}$ & $\mathrm{~S}$ & $\mathrm{~S}$ & $\mathrm{R}$ & $\mathrm{S}$ & $\mathrm{S}$ & $\mathrm{R}$ & $\mathrm{S}$ & $\mathrm{S}$ \\
\hline $346-6$ & $\mathrm{R}$ & $\mathrm{R}$ & $\mathrm{S}$ & $\mathrm{R}$ & $\mathrm{R}$ & $\mathrm{S}$ & $\mathrm{S}$ & $\mathrm{R}$ & $\mathrm{S}$ & $\mathrm{S}$ \\
\hline $346-7$ & $S$ & $\mathrm{~S}$ & $\mathrm{~S}$ & $\mathrm{~S}$ & S & $\mathrm{S}$ & $S$ & $\mathrm{R}$ & $\mathrm{R}$ & $S$ \\
\hline $346-8$ & $\mathrm{R}$ & $\mathrm{R}$ & $\mathrm{S}$ & $\mathrm{S}$ & S & $\mathrm{S}$ & S & S & $S$ & $\mathrm{~S}$ \\
\hline $346-10$ & $\mathrm{~S}$ & $\mathrm{~S}$ & $\mathrm{~S}$ & $\mathrm{~S}$ & $\mathrm{R}$ & $\mathrm{S}$ & $\mathrm{S}$ & $\mathrm{S}$ & $\mathrm{S}$ & $\mathrm{S}$ \\
\hline $346-11$ & $\mathrm{R}$ & $\mathrm{R}$ & $\mathrm{S}$ & $\mathrm{R}$ & $\mathrm{R}$ & $\mathrm{S}$ & $\mathrm{S}$ & $\mathrm{S}$ & $\mathrm{R}$ & $\mathrm{S}$ \\
\hline $346-12$ & $\mathrm{~S}$ & $\mathrm{~S}$ & $\mathrm{~S}$ & $\mathrm{R}$ & $\mathrm{R}$ & $\mathrm{S}$ & $\mathrm{S}$ & $\mathrm{R}$ & $\mathrm{R}$ & $\mathrm{S}$ \\
\hline $346-21$ & S & $\mathrm{S}$ & $\mathrm{S}$ & $\mathrm{S}$ & S & $\mathrm{S}$ & $S$ & $\mathrm{R}$ & $\mathrm{R}$ & $\mathrm{S}$ \\
\hline $346-22$ & $\mathrm{R}$ & $\mathrm{R}$ & $\mathrm{S}$ & S & $\mathrm{R}$ & S & $\mathrm{S}$ & $\mathrm{R}$ & S & $\mathrm{S}$ \\
\hline $346-23$ & $\mathrm{R}$ & $\mathrm{R}$ & $\mathrm{S}$ & $\mathrm{R}$ & $\mathrm{R}$ & $\mathrm{S}$ & $S$ & $\mathrm{R}$ & $\mathrm{R}$ & $\mathrm{S}$ \\
\hline $346-25$ & $\mathrm{~S}$ & $\mathrm{~S}$ & $\mathrm{~S}$ & $\mathrm{~S}$ & $\mathrm{~S}$ & $\mathrm{~S}$ & $\mathrm{~S}$ & $\mathrm{R}$ & $\mathrm{R}$ & $\mathrm{S}$ \\
\hline $346-26$ & $\mathrm{R}$ & $\mathrm{R}$ & $\mathrm{s}$ & $\mathrm{S}$ & $\mathrm{S}$ & $\mathrm{S}$ & $\mathrm{S}$ & $\mathrm{R}$ & $\mathrm{R}$ & $\mathrm{S}$ \\
\hline $346-27$ & $\mathrm{R}$ & $\mathrm{R}$ & S & $\mathrm{S}$ & $S$ & $\mathrm{~S}$ & $\mathrm{R}$ & S & $\mathrm{R}$ & $\mathrm{R}$ \\
\hline $346-28$ & S & $\mathrm{S}$ & $\mathrm{S}$ & $\mathrm{S}$ & $S$ & $\mathrm{~S}$ & S & S & S & $\mathrm{R}$ \\
\hline $346-29$ & $S$ & $\mathrm{~S}$ & $S$ & $\mathrm{~S}$ & $S$ & $\mathrm{~S}$ & $S$ & S & $S$ & $\mathrm{R}$ \\
\hline $346-31$ & $\mathrm{R}$ & $\mathrm{R}$ & $\mathrm{S}$ & $\mathrm{S}$ & $S$ & $\mathrm{~s}$ & $\mathrm{~S}$ & $\mathrm{~S}$ & $\mathrm{~S}$ & $\mathrm{R}$ \\
\hline $346-32$ & $\mathrm{~S}$ & $\mathrm{~s}$ & $\mathrm{~s}$ & $\mathrm{~S}$ & $\mathrm{~S}$ & $\mathrm{~s}$ & $\mathrm{~S}$ & $\mathrm{R}$ & $\mathrm{R}$ & $\mathrm{R}$ \\
\hline $346-34$ & $\mathrm{R}$ & $\mathrm{R}$ & $S$ & $\mathrm{R}$ & S & S & S & $\mathrm{R}$ & $\mathrm{R}$ & $\mathrm{R}$ \\
\hline $346-36$ & S & S & $S$ & $\mathrm{~S}$ & S & $\mathrm{S}$ & $\mathrm{R}$ & $\mathrm{R}$ & $\mathrm{R}$ & $\mathrm{R}$ \\
\hline $346-37$ & $\mathrm{~S}$ & $\mathrm{~S}$ & $\mathrm{~S}$ & $\mathrm{~S}$ & $\mathrm{~S}$ & $\mathrm{~S}$ & $\mathrm{~S}$ & $\mathrm{R}$ & $\mathrm{R}$ & $\mathrm{R}$ \\
\hline $346-38$ & S & $\mathrm{S}$ & $S$ & $\mathrm{~S}$ & $S$ & $\mathrm{R}$ & S & $S$ & $S$ & $S$ \\
\hline $346-39$ & $\mathrm{~S}$ & $\mathrm{~S}$ & $\mathrm{~S}$ & $\mathrm{~s}$ & $\mathrm{~S}$ & $\mathrm{~S}$ & $\mathrm{~S}$ & $\mathrm{~S}$ & $\mathrm{R}$ & $\mathrm{S}$ \\
\hline $346-40$ & S & $\mathrm{S}$ & S & $\mathrm{S}$ & S & S & S & S & $\mathrm{R}$ & S \\
\hline $346-41$ & $\mathrm{R}$ & $\mathrm{R}$ & $\mathrm{R}$ & $\mathrm{R}$ & $\mathrm{R}$ & $\mathrm{R}$ & $\mathrm{R}$ & $\mathrm{R}$ & $\mathrm{R}$ & $\mathrm{R}$ \\
\hline $346-42$ & $S$ & $\mathrm{~S}$ & $S$ & $\mathrm{~S}$ & S & $\mathrm{S}$ & $S$ & $S$ & $\mathrm{R}$ & $\mathrm{R}$ \\
\hline $346-43$ & S & $\mathrm{S}$ & $S$ & $\mathrm{~S}$ & S & $\mathrm{S}$ & S & $\mathrm{R}$ & $\mathrm{R}$ & $\mathrm{R}$ \\
\hline $346-46$ & $\mathrm{R}$ & $\mathrm{R}$ & S & $\mathrm{S}$ & S & $\mathrm{S}$ & $\mathrm{R}$ & S & $\mathrm{R}$ & $S$ \\
\hline $346-48$ & $\mathrm{~S}$ & S & S & $\mathrm{S}$ & $S$ & $\mathrm{~S}$ & $\mathrm{R}$ & $\mathrm{R}$ & $\mathrm{R}$ & $S$ \\
\hline $346-49$ & $\mathrm{R}$ & $\mathrm{R}$ & $S$ & $\mathrm{~S}$ & S & $\mathrm{S}$ & S & S & S & $\mathrm{S}$ \\
\hline $346-50$ & $\mathrm{R}$ & $\mathrm{R}$ & S & $\mathrm{S}$ & S & $\mathrm{S}$ & S & S & $S$ & $\mathrm{R}$ \\
\hline $346-52$ & S & $\mathrm{S}$ & S & $\mathrm{S}$ & S & $\mathrm{S}$ & S & $\mathrm{S}$ & $S$ & $\mathrm{~S}$ \\
\hline $346-53$ & S & S & S & $\mathrm{S}$ & $\mathrm{R}$ & $\mathrm{R}$ & $\mathrm{R}$ & $\mathrm{R}$ & $S$ & $\mathrm{R}$ \\
\hline $346-57$ & $\mathrm{R}$ & $\mathrm{R}$ & $\mathrm{R}$ & $\mathrm{R}$ & $\mathrm{R}$ & $\mathrm{R}$ & $\mathrm{R}$ & S & $\mathrm{R}$ & $\mathrm{R}$ \\
\hline $346-58$ & $\mathrm{R}$ & $\mathrm{R}$ & $\mathrm{R}$ & $\mathrm{R}$ & S & $\mathrm{S}$ & S & S & S & $\mathrm{R}$ \\
\hline $346-59$ & S & $\mathrm{S}$ & S & S & S & $\mathrm{S}$ & S & S & $\mathrm{R}$ & $\mathrm{R}$ \\
\hline $346-60$ & $\mathrm{R}$ & $\mathrm{R}$ & $\mathrm{S}$ & $\mathrm{R}$ & $\mathrm{S}$ & $\mathrm{S}$ & $\mathrm{S}$ & $\mathrm{R}$ & $\mathrm{s}$ & $\mathrm{S}$ \\
\hline
\end{tabular}

$R$ resistant phenotype, $S$ susceptible phenotype

three populations originating from distant genotypes supports the high similarity existing among the bittersweet populations described earlier. This result might indicate that this gene is widely distributed and that it helps to protect $S$. dulcamara from late blight attacks during the growing season. Because this gene does not provide 
immunity to the disease, it is likely that other, even more resistant individuals identified by us in parallel field assays (data not shown) possess additional resistance genes that are different from the one described here. Rpi-dlcl is the first resistance gene or strong QTL identified in a Solanum species native to the Eurasian continent. Thus, our result shows that not only the Solanaceae of America is a source of resistant genes to late blight.

The current literature shows that there is no indication that $S$. dulcamara coevolved with $P$. infestans until around 1840s when this oomycete arrived in Europe. The devastation of cultivated potato could have been accompanied by attacks of late blight on native Solanum species such as $S$. dulcamara and S. nigrum. De Bary (1876) already noticed attacks on shaded leaves of $S$. dulcamara, but he did not mention massive disease on individuals in nature. We can think of several hypotheses that might explain the observation of S. dulcamara being a species capable of defending itself against a completely new pathogen through functional $\mathrm{R}$ genes. First, it is possible that $\mathrm{R}$ genes were recruited from a general reservoir of functional $\mathrm{R}$ genes that must have been present at the time of arrival and subsequent epidemics from 1845s onwards. Likely, these genes were present in the population at low frequency, thus massive attacks must have occurred in the natural populations of $S$. dulcamara, leaving a population merely resistant. This then could explain the high genetic similarity and lack of clear structure in bittersweet populations as we observed (Golas et al. 209, submitted). However, to our knowledge, there are no reports of massive attacks of S. dulcamara plants in 1845 or later. This was probably due to the lack of knowledge of a true cause of the disease. Only from the 1870s people became aware of $P$. infestans being the cause of late blight.

Secondly, $\mathrm{R}$ genes such as Rpi-dlcl could operate against different, yet unknown pathogens, but with a pleiotropic effect on late blight. An example of such a situation is the $M i$-gene in tomato that is functional against the nematode Meloidogyne incognita as well as aphids and white flies (Goggin et al. 2001; Nombela et al. 2003).

A third, but less likely hypothesis, is that $P$. infestans was present in Europe long before 1845. Hence, S. dulcamara and other European Solanaceous weedy species could already have been evolutionary adapted and capable of resisting infection. Then, it has to be hypothesized that recorded epidemics in potato were not the results of a newly introduced pathogen, but rather an adaptation of $P$. infestans from a non to a highly pathogenic status with regard to the potato as a susceptible host. However, $P$. infestans sequences from herbarium material collected during the 1850s epidemics in Ireland link the European strain of $P$. infestans directly to the South American population (May and Ristaino 2004; Gomez-Alpizar et al. 2007).
In conclusion, in this paper, we have described the first $\mathrm{R}$ locus that confers resistance to P. infestans in S. dulcamara, a European Solanum weed. Another Solanum species widely distributed in Europe is $S$. nigrum, in which resistance to $P$. infestans was recently described by Lebecka (2009). Also in S. nigrum, as in S. dulcamara, the resistance seems to be conferred by a single locus, although in $S$. nigrum the genetic position is still unknown. Our results, however, indicate that in S. dulcamara other Rpi genes are present, similarly to the tuber-bearing American Solanum species. Comparison of all these Rpi genes may in the future help to elucidate the evolutionary processes that shaped resistance in plants.

Acknowledgments The authors acknowledge CBSG for funding this project. Thanks also go to Dirk Budding who passed away in 2008 and Vivianne Vleeshouwers for help with the detached leaf assays. Authors also want to thank the gardeners of RU Botanical and Experimental Garden for their help with maintenance of S. dulcamara plants.

Open Access This article is distributed under the terms of the Creative Commons Attribution Noncommercial License which permits any noncommercial use, distribution, and reproduction in any medium, provided the original author(s) and source are credited.

\section{References}

Ballvora A, Ercolano MR, Weiss J, Meksem K, Bormann CA, Oberhagemann P, Salamini F, Gebhardt C (2002) The Rl gene for potato resistance to late blight (Phytophthora infestans) belongs to the leucine zipper/NBS/LRR class of plant resistant genes. Plant J 30:361-371

Bradshaw JE, Bryan GJ, Lees AK, McLean K, Solomon-Blackburn RM (2006) Mapping the $R 10$ and $R 11$ genes for resistance to late blight (Phytophthora infestans) present in the potato (Solanum tuberosum) R-gene differentials of Black. Theor Appl Genet 112:744-751

Brommonschenkel SH, Tanksley SD (1997) Map-based cloning of the tomato genomic region that spans the $S w-5$ tospovirus resistance gene in tomato. Mol Gen Genet 256:121-126

Chunwongse J, Chunwongse C, Black L, Hanson P (2002) Molecular mapping of the $P h-3$ gene for late blight resistance in tomato. J Hort Sci Biotechnol 77:281-286

Cooke LR, Carlisle DJ, Wilson DG, Deahl KL (2002) Natural occurrence of Phytophthora infestans on woody nightshade (Solanum dulcamara) in Ireland. Plant Pathol 51:392

De Bary A (1876) Researches into the nature of the potato fungus, Phytophthora infestans. J Roy Agr Soc Engl 12:357-391

El-Kharbotly A, Leonards-Schippers C, Huigen DJ, Jacobsen E, Pereira A, Stiekema WJ, Salamini F, Gebhardt C (1994) Segregation analysis and RFLP mapping of the $R 1$ and $R 3$ alleles conferring race-specific resistance to Phytophthora infestans in progeny of dihaploid potato parents. Mol Gen Genet 242:749-754

El-Kharbotly A, Palomino-Sánchez C, Salamini F, Jacobsen E, Gebhardt C (1996) $R 6$ and $R 7$ alleles of potato conferring racespecific resistance to Phytophthora infestans (Mont.) de Bary identified genetic loci clustering with the $R 3$ locus on chromosome 9. Theor Appl Genet 92:880-884 
Flier WG, Van den Bosh GBM, Turkensteen LJ (2003) Stability of partial resistance in potato cultivars exposed to aggressive strains of Phytophthora infestans. Plant Pathol 52:326-337

Foster SJ, Park TH, Pel M, Brigneti G, Sliwka J, Jagger L, Van der Vossen E, Jones JDG (2009) Rpi-vnt1.1, a Tm-2 homolog from Solanum venturii confers resistance to potato late blight. Mol Plant Microbe Interact 22:589-600

Fry WE (2007) The canon of potato science: 10. Late blight and early blight. Potato Res 50:243-345

Fry WE, Goodwin SB (1997) Resurgence of the Irish potato famine fungus. Bioscience 47:363-367

Gebhardt C, Valkonen JPT (2001) Organization of genes controlling disease resistance in the potato genome. Ann Rev Phytopathol 39:79-102

Goggin FL, Williamson VM, Ullman DE (2001) Variability in the response of Macrosiphum euphorbiae and Myzus persicae (Hemiptera: Aphididae) to the tomato resistance gene Mi. Envir Entomol 30:101-106

Golas TM, Feron RMC, Van den Berg R, Van der Weerden GM, Mariani C, Allefs JJHM (2009) Genetic structure of European Solanum dulcamara L (submitted)

Gomez-Alpizar L, Carbone I, Beagle Ristaino J (2007) An andean origin of Phytophthora infestans inferred from nuclear and mitochondrial gene genealogies. PNAS 104(9):3306-3311

Goodwin SB, Drenth A (1997) Origin of the A2 mating type of Phytophthora infestans outside Mexico. Phytopathol 87:992-999

Goodwin SB, Sujkowski LS, Fry WE (1996) Widespread distribution and probable origin of resistance to metalaxyl in clonal genotypes of Phytophthora infestans in the United States and Western Canada. Phytopathol 86:793-800

Grünwald NJ, Flier WG, Sturbaum AK, Garay-Serrano E, Van den Bosh TBM, Smart CD, Matuszak JM, Lozoya-Saldana H, Turkensteen LJ, Fry WE (2001) Population structure of Phytophthora infestans in the Toluca valley region of central Mexico. Phytopathol 91:882-890

Haverkort AJ, Boonekamp PM, Hutten R, Jacobsen E, Lotz LAP, Kessel GJT, Visser RGF, Van der Vossen EAG (2008) Societal costs of late blight in potato and prospects of durable resistance through cisgenic modification. Potato Res 51:47-57

Helgeson JP, Pohlman JD, Austin S, Haberlach GT, Wielgus SM, Ronis D, Zambolim L, Tooley P, McGrath JM, James RV, Stevenson WR (1998) Somatic hybrids between Solanum bulbocastanum and potato: a new source of resistance to late blight. Theor Appl Genet 96:738-742

Huang S, Vleeshouwers VGAA, Werij JS, Hutten RCB, Van Eck HJ, Visser RGF, Jacobsen E (2004) The R3 resistance to Phytophthora infestans in potato is conferred by two closely linked $\mathrm{R}$ genes with distinct specificities. Mol Plant Microbe Interact 17:428-435

Huang S, Van der Vossen EAG, Huang H, Vleeshouwers VGAA, Zhang N, Borm TJA, Van Eck HJ, Baker B, Jacobsen E, Visser $\mathrm{R}$ (2005) Comparative genomics enabled the isolation of the $R 3 a$ late blight resistance gene in potato. Plant J 42:251-261

Kuhl JC, Hanneman RE, Havey MJ (2001) Characterization and mapping of Rpil, a late blight resistance locus from diploid (1EBN) Mexican Solanum pinnatisectum. Mol Genet Genomics 265:977-985

Lebecka R (2008) Host-pathogen interaction between Phytophthora infestans and Solanum nigrum, S. villosum and S. scabrum. Eur J Plant Pathol 120:233-240

Lebecka R (2009) Inheritance of resistance in Solanum nigrum to Phytophthora infestans. Eur J Plant Pathol 124:345-348

Leonards-Schippers C, Gieffers W, Salamini F, Gebhardt C (1992) The $R 1$ gene conferring race specific resistance to Phytophthora infestans in potato is located on potato chromosome 5. Mol Gen Genet 233:278-283
Li X, Van Eck HJ, Rouppe van der Voort JNAM, Huigen DJ, Stam P, Jacobsen E (1998) Autotetraploids and genetic mapping using common AFLP markers: the $R 2$ allele conferring resistance to Phytophthora infestans mapped on potato chromosome 4. Theor Appl Genet 96:1121-1128

May KJ, Ristaino JB (2004) Identity of the mitochondrial DNA haplotype(s) in historic specimens from the Irish potato famine. Mycol Res 108:171-179

Michelmore RW, Paran I, Kesseli RV (1991) Identification of markers linked to disease-resistance genes by bulked segregant analysis: a rapid method to detect markers in specific genomic regions by using segregating populations. Proc. Natl. Acad. Sci. (USA) 88:9828-9832

Muller KO (1951) Über die Herkunft der W-sorten, ihre Entwicklungssgeschichte und ihre bisherige Nutzung in der praktischen Kartoffelzuchtung. Zeitschrift fur Pflanzenzuchtung 29:366-387

Nakitandwe J, Trognitz F, Trognitz B (2007) Genetic mapping of Solanum caripense, a wild relative of pepino dulce, tomato and potato, and a genetic resource for resistance to potato late blight. Acta Hort 745:333-342

Naess SK, Bradeen JM, Wielgus SM, Haberlach GT, McGrath JM, Helgeson JP (2000) Resistance to late blight in Solanum bulbocastanum is mapped to chromosome 8. Theor Appl Genet 101:697-704

Nombela G, Williamson VM, Muniz M (2003) The root-knot nematode resistance gene Mi-1.2 of tomato is responsible for resistance against the whitefly Bemisia tabaci. Mol Plant Microbe Interact 16(7):645-649

Park TH, Gros J, Sikkema A, Vleeshouwers VGAA, Muskens M, Allefs S, Jacobsen E, Visser RGF, Van der Vossen EAG (2005) The late blight resistance locus Rpi-blb3 from Solanum bulbocastanum belongs to a major late blight $\mathrm{R}$ gene cluster on chromosome 4 of potato. Mol Plant Microbe Interact 18:722729

Park TH, Foster S, Brigneti G, Jones JDG (2009) Two distinct potato late blight resistance genes from Solanum berthaultii are located on chromosome 10. Euphytica 165(2):269-278

Pel M, Foster SJ, Park TH, Rietman H, Van Arkel G, Jones JDG, Van Eck HJ, Jacobsen E, Visser RGF, Van der Vossen EAG (2009) Mapping and cloning of late blight resistance genes from Solanum venturii using an interspecific candidate gene approach. Mol Plant Microbe Interact 22:601-615

Rouppe van der Voort J, Van der Vossen E, Bakker E, Overmars H, Van Zandvoort P, Hutten R, Klein Lankhorst R, Bakker J (2000) Two additive QTLs conferring broad-spectrum resistance in potato to Globodera pallida are localized on resistance gene clusters. Theor Appl Genet 101:1122-1130

Sandbrink JM, Colon LT, Wolters PJCC, Stiekema WJ (2000) Two related genotypes of Solanum microdontum carry different segregating alleles for field resistance to Phytophthora infestans. Mol Breed 6:215-225

Sliwka J, Jakuczun H, Lebecka R, Marczewski W, Gebhardt C, Zimnoch-Guzowska E (2006) The novel, major locus Rpi-phul for late blight resistance maps to potato chromosome 9 and is not correlated with long vegetation period. Theor Appl Genet 113:685-695

Smilde WD, Brigneti G, Jagger L, Perkins S, Jones JDG (2005) Solanum mochiquense chromosome IX carries a novel late blight resistance gene Rpi-moc1. Theor Appl Genet 110:252258

Song J, Bradeen JM, Naess SK, Raasch JA, Wielgus SW, Haberlach GT, Liu J, Kuang H, Austin-Phillips S, Buell CR, Helgeson JP, Jiang J (2003) Gene RB cloned from Solanum bulbocastanum confers broad spectrum resistance to potato late blight. Proc. Natl. Acad. Sci. (USA) 100:9128-9133 
Tan MYA, Hutten RCB, Celis C, Park TH, Niks RE, Visser RGF, Van Eck HJ (2008) The RPi-mcdl locus from Solanum microdontum involved in resistance to Phytophthora infestans, causing a delay in infection, maps on potato chromosome 4 in a cluster of NBS-LRR genes. Mol Plant Microbe Interact 21:909_ 918

Tommiska TJ, Hamalainen JH, Watanabe KN, Valkonen JPT (1998) Mapping of the gene Nxphu that controls hypersensitive resistance to potato virus X in Solanum phureja IvP35 Theor. Appl. Genet 96:840-843

Trognitz F, Trognitz B (2004) Mapping genes of Solanum caripense involved in resistance to Phytophthora infestans, the causal agent of potato late blight. Genetic variation for plant breeding. Proceedings of the 17th Eucarpia General Congress, Tulln, Austria, 8-11 September 2004

Van der Vossen E, Sikkema A, te Lintel Hekkert B, Gros J, Stevens P, Muskens M, Wouters D, Pereira A, Stiekema W, Allefs S (2003) An ancient $\mathrm{R}$ gene from the wild potato species Solanum bulbocastanum confers broad-spectrum resistance to Phytophthora infestans in cultivated potato and tomato. Plant J 36:867882

Van der Vossen E, Gros JE, Sikkema A, Muskens M, Wouters D, Wolters P, Pereira A, Allefs S (2005) The Rpi-blb2 gene from Solanum bulbocastanum is an Mi-1 gene homolog conferring broad-spectrum late blight resistance in potato. Plant J 44:208222

Van Os H, Andrzejewski S, Bakker E, Barrena I, Bryan GJ, Caromel B, Ghareeb B, Isidore E, De Jong W, Van Koert P, Lefebvre V,
Milbourne D, Ritter E, Rouppe Van der Voort JNAM, RousselleBourgeois F, Van Vliet J, Waugh R, Visser RGF, Bakker J, van Eck H (2006) Construction of a 10, 000-marker ultradense genetic recombination map of potato: providing a framework for accelerated gene isolation and a genome wide physical map. Genetics 173:1075-1087

Villamon FG, Spooner DM, Orrillo M, Mihovilovich E, Perez W, Bonierbale M (2005) Late blight resistance linkages in a novel cross of the wild potato species Solanum paucissectum (series Piurana). Theor Appl Genet 111:1201-1214

Vleeshouwers VGAA, Van Dooijeweert W, Keizer LCP, Sijpkes L, Govers F, Colon LT (1999) A laboratory assay for Phytophthora infestans resistance in various Solanum species reflects the field situation. Eur J Plant Pathol 105:241-250

Vos P, Hogers R, Bleeker M, Reijans M, Van der Lee T, Hornes M, Frijters A, Pot J, Pelemann J, Kuiper M, Zabeau M (1995) AFLP: a new technique for DNA fingerprinting. Nucl Acids Res 23:4407-4414

Wang M, Allefs S, Van den Berg R, Vleeshouwers VGAA, Van der Vossen EAG, Vosman B (2008) Allele mining in Solanum: conserved homologues of Rpi-blb1 are identified in Solanum stoloniferum. Theor Appl Genet 116:933-943

Wastie RL (1991) Breeding for resistance. Adv Plant Pathol 7:193224

Weese TL, Bohs L (2007) A three-gene phylogeny of the genus Solanum (Solanaceae). Syst Bot 32:445-463 